\title{
Lipid Inhibitory Effect of (-)-loliolide Isolated from Sargassum horneri in 3T3-L1 Adipocytes: Inhibitory Mechanism of Adipose-Specific Proteins
}

\author{
Hyo-Geun Lee ${ }^{1}$, Hyun-Soo Kim ${ }^{2,+}{ }^{\text {, Jun-Geon Je }}{ }^{1}$, Jin Hwang ${ }^{1}$, K. K. Asanka Sanjeewa ${ }^{1} \mathbb{D}$, Dae-Sung Lee ${ }^{2} \mathbb{D}$, \\ Kyung-Mo Song ${ }^{3}$, Yun-Sang Choi ${ }^{3}{ }^{(\mathbb{D}}$, Min-Cheol Kang ${ }^{3, *,+}$ and You-Jin Jeon ${ }^{1, *},+(\mathbb{C}$ \\ 1 Department of Marine Life Science, Jeju National University, Jeju 63243, Korea; \\ hyogeunlee92@jejunu.ac.kr (H.-G.L.); wpwnsrjs3@jejunu.ac.kr (J.-G.J.); ghkdwls9280@jejunu.ac.kr (J.H.); \\ asanka@jejunu.ac.kr (K.K.A.S.) \\ 2 Marine Biodiversity Institute of Korea, 75, Jangsan-ro 101-gil, Janghang-eup, Seocheon 33362, Korea; \\ gustn783@mabik.re.kr (H.-S.K.); daesung@mabik.re.kr (D.-S.L.) \\ 3 Research Group of Food Processing, Korea Food Research Institute, 245, Nongsaengmyeong-ro, Iseo-myeon, \\ Wanju 55365, Korea; rudah@kfri.re.kr (K.-M.S.); kcys0517@kfri.re.kr (Y.-S.C.) \\ * Correspondence: mckang@kfri.re.kr (M.-C.K.); youjinj@jejunu.ac.kr (Y.-J.J.); \\ Tel.: +82-10-3358-6290 (M.-C.K.); +82-10-4572-3624 (Y.-J.J.); Fax: +82-64-756-3493 (Y.-J.J.) \\ $\dagger$ These co-first authors contributed equally to this work.
}

check for updates

Citation: Lee, H.-G.; Kim, H.-S.; Je, J.-G.; Hwang, J.; Sanjeewa, K.K.A.; Lee, D.-S.; Song, K.-M.; Choi, Y.-S.; Kang, M.-C.; Jeon, Y.-J. Lipid Inhibitory Effect of (-)-loliolide Isolated from Sargassum horneri in 3T3-L1 Adipocytes: Inhibitory Mechanism of Adipose-Specific Proteins. Mar. Drugs 2021, 19, 96. https://doi.org/10.3390/md19020096

Academic Editor: Bill J. Baker

Received: 18 January 2021

Accepted: 2 February 2021

Published: 8 February 2021

Publisher's Note: MDPI stays neutral with regard to jurisdictional claims in published maps and institutional affiliations.

Copyright: (c) 2021 by the authors. Licensee MDPI, Basel, Switzerland. This article is an open access article distributed under the terms and conditions of the Creative Commons Attribution (CC BY) license (https:// creativecommons.org/licenses/by/ $4.0 /)$.

\begin{abstract}
Sargassum horneri (S. horneri) is a well-known brown seaweed widely distributed worldwide. Several biological activities of $S$. horneri have been reported. However, its effects on lipid metabolism and the underlying mechanisms remain elusive. In the present study, we examined the inhibitory effect of the active compound "(-)-loliolide ((6S,7aR)-6-hydroxy-4,4,7a-trimethyl5,6,7,7a-tetrahydro-1-benzofuran-2(4H)-one (HTT))" from S. horneri extract on lipid accumulation in differentiated adipocytes. MTT assays demonstrated that (-)-loliolide is not toxic to 3T3-L1 adipocytes in a range of concentrations. (-)-loliolide significantly reduced intracellular lipid accumulation in the differentiated phase of 3T3-L1 adipocytes as shown by Oil Red O staining. Western blot analysis revealed that (-)-loliolide increased the expression of lipolytic protein phospho-hormonesensitive lipase (p-HSL) and thermogenic protein peroxisome proliferator-activated receptor gamma coactivator 1-alpha (PGC-1). Additionally, (-)-loliolide decreased expression of adipogenic and lipogenic proteins, including sterol regulatory element-binding protein-1 (SREBP-1), peroxisome proliferator-activated receptor- $\gamma$ (PPAR- $\gamma$ ), CCAAT/enhancer-binding protein- $\alpha(\mathrm{C} / \mathrm{EBP}-\alpha)$, and fatty acid-binding protein 4 (FABP4) in 3T3-L1 adipocytes. These results indicate that (-)-loliolide from $S$. horneri could suppress lipid accumulation via regulation of antiadipogenic and prolipolytic mechanisms in 3T3-L1 cells. Considering the multifunctional effect of (-)-loliolide, it can be useful as a lipid-lowering agent in the management of patients who suffer from obesity.
\end{abstract}

Keywords: Sargassum horneri; (-)-loliolide; lipid metabolism; 3T3-L1 adipocytes

\section{Introduction}

Due to its steadily increasing rates, obesity is regarded as a global epidemic and public health concern [1]. Based on statistics, more than 2.1 billion people are either overweight or suffer from obesity, and approximately 3.4 million obese patients die annually [2]. Pediatric and childhood obesity have increased in the last few decades, with obese children and adolescents accounting for approximately $21-24 \%$ of obesity patients [3]. Childhood obesity is closely related to adult obesity, develops more easily into adult obesity, and is accompanied by an increased risk of obesity-related diseases such as cancer and cardiovascular disease [4-6]. Indeed, childhood obesity and obesity-related comorbidities increase the incidence of cardiovascular disease and nonalcoholic fatty liver disease in children and adolescents [7]. Therefore, several guidelines and programs have been reported for 
the treatment of childhood obesity [8]. The World Health Organization (WHO) defines overweight and obesity as abnormal or excessive fat accumulation in the body, with a body mass index (BMI) over 30. The imbalance of energy expenditure and calorie intake in the human body can induce overweight or obesity. A number of complex interactions between genetics, behavior, and environmental factors affects the development of obesity [9]. Obese patients have high levels of triglyceride (TG), total cholesterol (TC), decreased high-density lipoprotein (HDL), and abnormal low-density lipoprotein (LDL) composition [10]. High TG and cholesterol levels can induce severe metabolic disorders [11]. Moreover, abnormally elevated TG and cholesterol levels increase the risk of several comorbidities such as diabetes mellitus, cardiovascular disease, and cancer [12]. Accordingly, obesity increases the risk of metabolic diseases. Han and Mike (2016) reported that the clinical perspective of obesity, metabolic syndrome, cardiovascular disease (CVD), and coronary heart diseases (CHD) and their symptoms can be improved by decreasing TG, TC, and HDL levels [13]. Long-lasting overweight conditions exacerbate adverse effects, such as cardiometabolic risk factors that induce cardiovascular diseases, including CHD, stroke, and diabetes mellitus [14]. Thus, commercial anti-obesity agents have been developed in the medicinal industry to treat patients who suffer from obesity. Currently, several kinds of commercial anti-obesity drugs have been developed worldwide [15]. Among these, orlistat (Xenical) and sibutramine (Meridia) are the most commonly used anti-obesity agents to treat obesity. Orlistat was approved by the U.S. Food and Drug Administration (FDA). In general, Xenical reduces fat absorption from the intestine via suppression of gastric and pancreatic lipase activity. This breaks down the TG and reduces fat accumulation in the body [16]. However, orlistat has some undesirable side effects such as oily bowel steatorrhea [17]. In addition, prolonged use of orlistat was also found to induce toxicity in the human pancreas and kidney [18]. Sibutramine deactivates neurotransmitters, which are chemical messengers between neurons and target cells. In turn, this blocks the reuptake of serotonin and norepinephrine and may increase serotonin levels that induce satiety and decrease appetite [19]. However, sibutramine also has various adverse effects, including headaches, insomnia, and amnesia [20]. Therefore, the development of new natural anti-obesity agents is an urgent requirement to treat obese patients without inducing side effects. Most studies on obesity have focused on the potential beneficial effects of natural products from land plants [21]. Furthermore, several publications have reported the excellent anti-obesity activities of marine-derived active compounds [22,23].

Sargassum horneri (S. horneri) belongs to the Sargassum genus, which is abundant in Korea and Japan. S. horneri extract has been used for medicinal purposes in traditional medicine [24]. In addition, the active component of $S$. horneri showed various biological properties, such as antioxidant, anti-inflammatory, anti-wrinkle, and immunomodulatory activities [25]. (-)-loliolide ((6S,7aR)-6-hydroxy-4,4,7a-trimethyl-5,6,7,7a-tetrahydro-1benzofuran-2(4H)-one (HTT)) is composed of a series of pigment compounds and exhibits antioxidant, anti-apoptotic, and antiviral activity [26-28]. However, the inhibitory effects of (-)-loliolide from S. horneri on lipid accumulation have rarely been investigated. Kwon et al. (2019) investigated the lipid inhibitory effect of an ethanol extract separated from S. horneri on 3T3-L1 adipocytes [29]. In the present study, the inhibitory effects of (-)-loliolide on lipid accumulation were determined in differentiated 3T3-L1 adipocytes [30]. Furthermore, adipose-specific protein expression was determined to investigate the intracellular lipid inhibitory mechanisms in vitro.

\section{Results}

2.1. (-)-loliolide Is not Cytotoxic and Inhibits Lipid Accumulation in Differentiated 3T3-L1 Cells

The cytotoxicity of different concentrations of (-)-loliolide $(0.125,0.25,0.5$, and $1 \mathrm{mM})$ was investigated in 3T3-L1 cells (Figure 1A). At the tested range, (-)-loliolide did not show cytotoxicity in 3T3-L1 cells. Thus, these nontoxic concentrations were selected for further experiments. Next, differentiation of 3T3-L1 cells was induced to promote adipogenesis and lipid accumulation. Figure 1B shows the accumulation of lipids in 3T3-L1 cells. High 
lipid accumulation was observed in the control group (untreated samples). However, treatment with (-)-loliolide significantly decreased intracellular lipid accumulation in differentiated 3T3-L1 cells. A significant reduction in lipid accumulation was detected in the (-)-loliolide -treated group. The isolation and purification procedure of (-)-loliolide from S. horneri were kindly described by Kim et al. (2020) [31] and the structure of (-)loliolide is represented in Figure 1D. These results indicate that supplementation with (-)-loliolide significantly suppressed lipid accumulation in 3T3-L1 adipocytes.

(A)

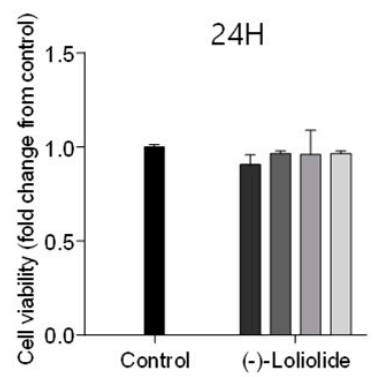

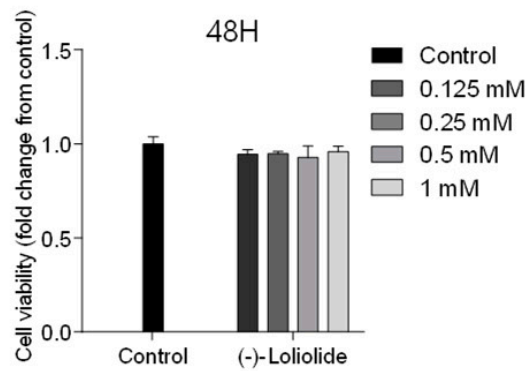

(B)

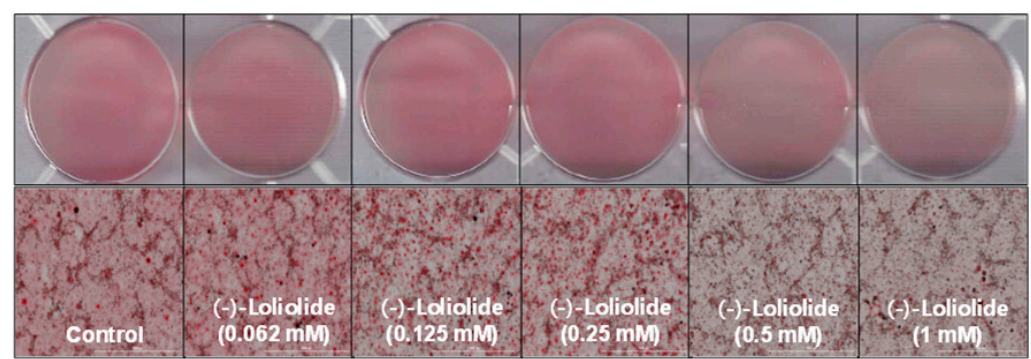

(C)

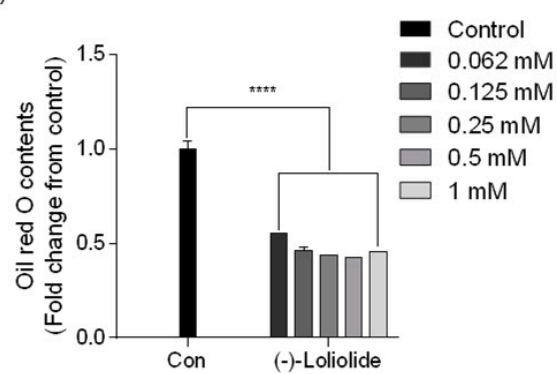

(D)

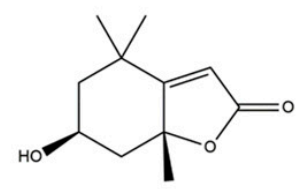

(-)-Loliolide ((6S,7aR)-6-hydroxy-4,4,7a-trim ethyl-5,6,7,7atetrahydro-1-benzofuran-2(4H)-one)

Figure 1. (-)-loliolide contrasts lipid accumulation in 3T3-L1 cells. (A) Cytotoxic effect of (-)-loliolide on cell viability in 3T3-L1 measured for 24 and 48 h. (B) Microscopic images of 3T3-L1 cells stained with Oil Red O (ORO) and (C) relative lipid accumulation. (D) The structure of $(-)$-loliolide. All data are presented as mean $\pm \operatorname{SD}(n=3)$. Significant differences were identified at ${ }^{* * * *} p<0.0001$ compared to the control group.

\section{2. (-)-loliolide Suppresses Adipogenic and Lipogenic Pathways in 3T3-L1 Cells}

Next, Western blot analysis was performed to elucidate the potential inhibitory effect of (-)-loliolide on expression of adipogenic and lipogenic proteins. The levels of adipogenic proteins peroxisome proliferator-activated receptor- $\gamma$ (PPAR- $\gamma)$, CCAAT/enhancer-binding protein- $\alpha(\mathrm{C} / \mathrm{EBP}-\alpha)$, and fatty acid-binding protein 4 (FABP4) were increased in control cells, which were only treated to induce adipocyte differentiation [32]. However, adipogenic protein expression was lower in the presence of (-)-loliolide. In particular, the highest concentration of (-)-loliolide $(1 \mathrm{mM})$ dramatically decreased the expression of the adipogenic proteins (Figure 2). In addition, the levels of lipogenic protein sterol regulatory element-binding protein-1 (SREBP-1) were significantly reduced following (-)-loliolide treatment. Taken together, these results suggest that (-)-loliolide strongly suppressed adipogenesis and lipogenesis by reducing expression of adipogenic and lipogenic proteins in 3T3-L1 cells. 
(A)

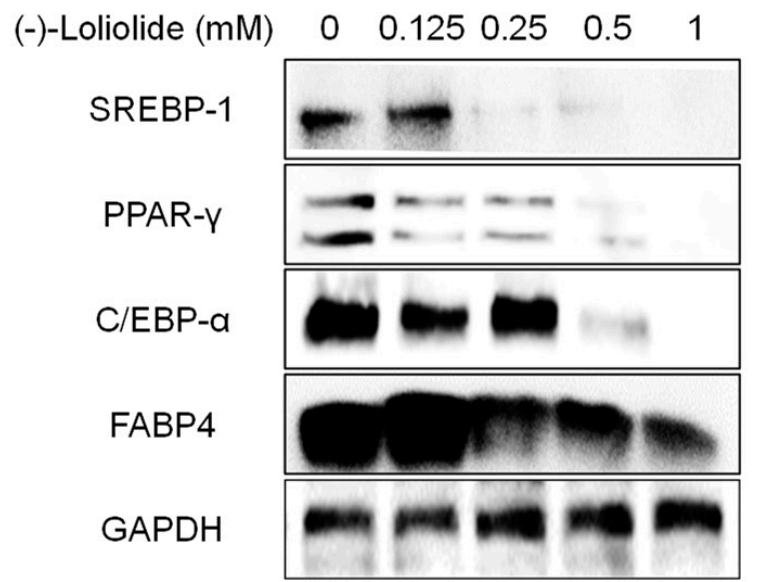

(B)

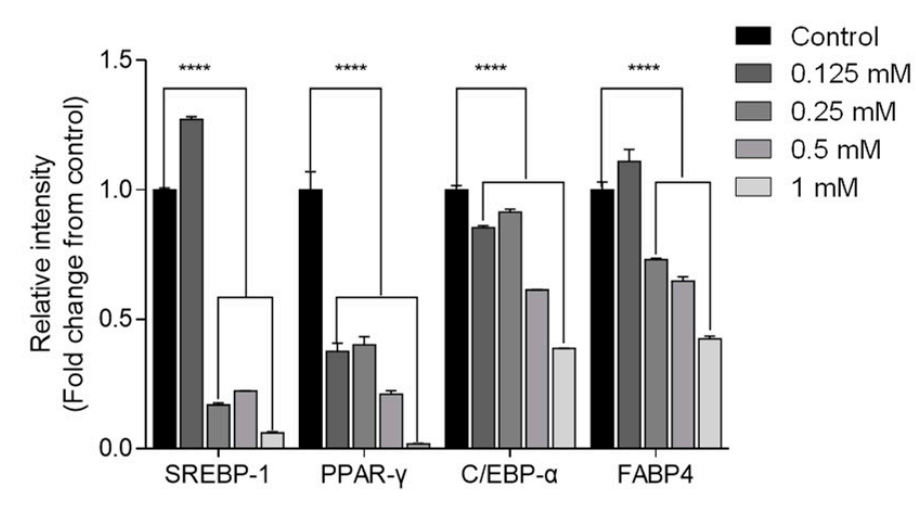

Figure 2. (-)-loliolide regulates adipogenesis and lipogenesis pathway enzyme expression in 3T3-L1 cells. (A) Western blot analysis of lipogenic SREBP-1 and adipogenic PPAR- $\gamma$, C/EBP- $\alpha$, and FABP4. (B) Quantification graph for expression of SREBP-1, PPAR- $\gamma$, C/EBP- $\alpha$, and FABP4. All data are presented as mean \pm SD $(n=3)$. Significant differences were identified at ${ }^{* * * *} p<0.0001$ compared to the control group.

\section{3. (-)-loliolide Regulates Thermogenesis and Lipolysis in 3T3-L1 Cells}

Next, we assessed whether (-)-loliolide stimulates the expression of thermogenic peroxisome proliferator-activated receptor- $\gamma$ coactivator- $1 \alpha$ (PGC- $1 \alpha)$ and lipolytic phosphohormone sensitive lipase (p-HSL) in 3T3-L1 cells by Western blot analysis. As shown in Figure 3, the expression of PGC- $1 \alpha$ and p-HSL, which was low in the control group, was considerably increased in (-)-loliolide-treated groups. These results suggest that (-)-loliolide from S. horneri could regulate lipolysis in vitro in 3T3-L1 cells.

(A)

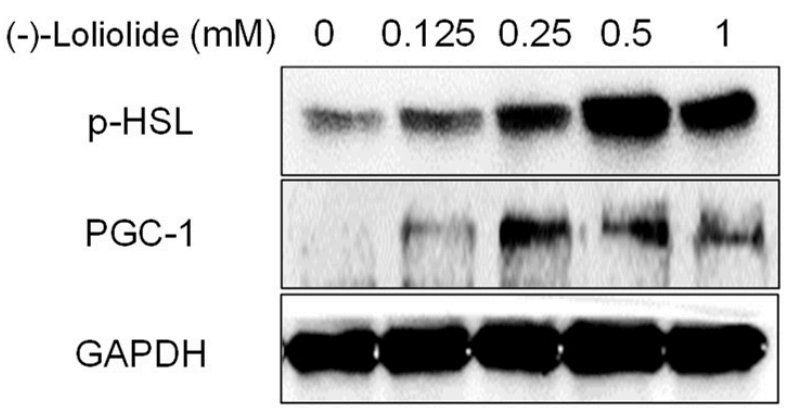

(B)

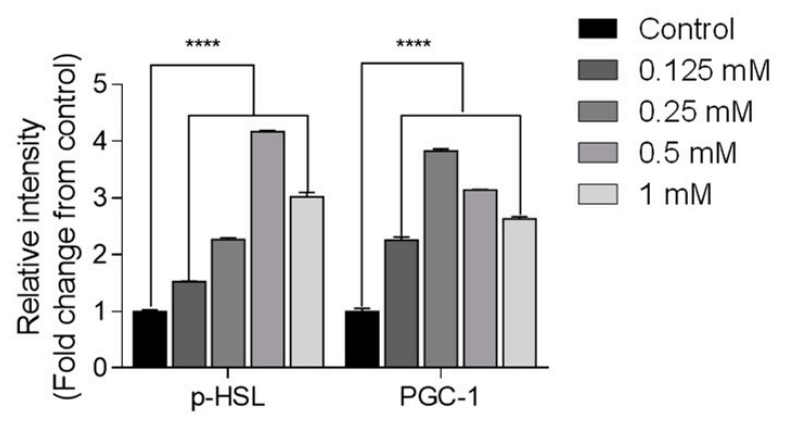

Figure 3. (-)-loliolide stimulates the expression of lipolytic and thermogenic proteins in 3T3-L1 cells. (A) Western blots showing expression of lipolytic protein p-HSL and thermogenic protein PGC-1. (B) Quantification graph for p-HSL and PGC-1 expressions. Significant differences were identified at ${ }^{* * * *} p<0.0001$ compared to the control group.

\section{Discussion}

Obesity is regarded as a public health problem, and the overweight and obese populations are steadily increasing [33]. Most importantly, the prevalence of obesity-related complications has also grown in the past few decades [34-36]. Epidemiological obesity studies have revealed that overweight and obese individuals worldwide account for $33 \%$ of the total population [37]. Numerous anti-obesity mechanisms regulate lipid metabolism in obese patients. Among these, the inhibition of lipid accumulation is one of the best strategies to improve and treat obesity. According to in vitro and in vivo studies, inhibition of adipogenic and lipolytic protein expression is one of the possible approaches to suppress 
lipid metabolism [38]. However, relatively low inhibitory effects of marine natural products on lipid metabolism were reported compared to those from land plants. Hypolipidemic effects of marine-derived polysaccharides have been reported [39-42]. Nevertheless, few anti-obesity studies have been published on marine peptides, polyphenolic compounds, and pigments [23,43-45]. Therefore, to fill this knowledge gap, we investigated the potential inhibitory effect of the phenolic compound (-)-loliolide isolated from S. horneri on lipid accumulation in 3T3-L1 cells.

Intracellular lipid accumulation is a normal process in the human body. However, high-calorie food intake or overnutrition can cause excessive lipid accumulation in the adipocytes, resulting in obesity and excess weight. Normally, intracellular lipid accumulation in adipocytes is controlled by adipose-specific proteins, including lipogenic protein SREBP-1 and adipogenic proteins PPAR- $\gamma$, C/EBP- $\alpha$, and FABP4. Adipogenic and lipogenic proteins play a crucial role in lipid metabolism, including lipid storage and synthesis in 3T3-L1 cells [46]. Sterol regulatory element-binding proteins (SREBPs), including SREBP-1a, SREBP-1c, and SREBP-2, are transcription factors. SREBP-1c regulates lipid synthesis and sterol levels and acts in concert with carbohydrate response element-binding protein (ChREBP) to stimulate de novo lipogenesis (DNL), which induces lipid synthesis in the adipose and liver tissues [47]. PPAR- $\gamma$ is regarded as the major adipogenic protein that regulates lipid and glucose metabolism. Adipogenesis starts with the expression of pro-adipogenic genes, including C/EBP- $\alpha, C / E B P-\beta$, and C/EBP- $\gamma$, which stimulate the expression of the key adipogenic protein PPAR- $\gamma[48,49]$. FABP4 is a lipid-trafficking protein controlled by PPAR- $\gamma$ that plays a pivotal role in the transport of lipids from the extracellular to the intracellular matrix in adipocytes [50]. According to Kim et al. (1998), the expression of SREBP-1 specifically increases PPAR $-\gamma$ activation by increasing endogenous ligands; moreover, adipose differentiation is controlled by interactions of transcriptional activation of PPAR- $\gamma$, C/EBPs, and SREBP-1 [51]. In addition, Horton et al. (2003) also reported that SREBP-1 expression affects the gene expression of PPAR- $\gamma$ and C/EBP- $\alpha$ [52]. It has been suggested that adipogenesis is a mechanism that sustains adipocyte functions. p-HSL, known as TG lipase in adipose tissues, plays a critical role in maintaining energy homeostasis and mobilization of stored fat in the body [53]. PGC-1 $\alpha$ is a transcriptional coactivator that regulates mitochondrial biogenesis by increasing the transcriptional activation of nuclear hormone receptors [54]. AMP-activated protein kinase (AMPK) plays an important role in sensing intracellular ATP levels and energy balance within the cells. According to Wan et al. (2014), AMPK regulates PGC- $1 \alpha$ expression and mitochondrial enzymes in adipose tissues [55]. In addition, phosphorylation of AMPK activates lipolytic enzymes such as adipose TG lipase (ATGL) and HSL in white adipose tissues [56,57].

In this study, we evaluated the inhibitory effect of (-)-loliolide on lipid accumulation in differentiated 3T3-L1 cells and further investigated the effect of this compound on lipogenic, adipogenic, lipolytic, and thermogenic proteins in 3T3-L1 cells. We demonstrated the potential of (-)-loliolide to reduce expression of lipogenic protein SREBP-1 and adipogenic proteins PPAR- $\gamma, \mathrm{C} / \mathrm{EBP}-\alpha$, and FABP4. These results are consistent with previous publications reporting hypolipidemic and anti-obesity activity of (-)-loliolide [58]. Furthermore, we found that the lipolytic p-HSL and thermogenic PGC- $1 \alpha$ protein expressions were higher in 3T3-L1 cells treated with a low concentration of (-)-loliolide suggesting that the range of 0.125 to $0.25 \mu \mathrm{g} / \mathrm{mL}$ is a critical concentration.

Our findings indicate that (-)-loliolide significantly reduced lipid accumulation via regulation of adipogenic, lipolytic, and thermogenic proteins in 3T3-L1 cells.

\section{Materials and Methods}

\subsection{Material and Reagents}

The lipid staining dye Oil Red O (ORO, catalog: O0625), thiazolyl blue tetrazolium bromide (MTT), cell differentiation reagents 3-isobutyl-1-methylxanthine (IBMX, catalog: 17018), dexamethasone (DM, catalog: D8893), and insulin (catalog: I5500) were purchased from Sigma-Aldrich Co. (St. Louis, MO, USA). Dulbecco's Modified Eagle's 
Medium (DMEM, catalog: 12430-054) and supplements including bovine serum (BS, catalog: 26170-043), fetal bovine serum (FBS, catalog: 16000-044), penicillin/streptomycin (P/S, catalog: 15140-122), and trypsin-ethylenediaminetetraacetic acid (Trypsin-EDTA, catalog: 15400-054) were purchased from GIBCO-BRL (Grand Island, NY, USA). Isopropanol (2-propanol, catalog: 5035-44) was purchased from Daejung Chemicals \& Materials (Siheung-si, Korea). Formalin (catalog: 6936050380) for cell fixation was purchased from Junsei (Tyoko, Japan). Primary antibodies against adipogenesis-related proteins, including PPAR- $\gamma$ (catalog: \#2443), C/EBP- $\alpha$ (catalog: \#2295) and FABP4 (catalog: \#2120), and against thermogenic proteins such as PGC-1 $\alpha$ (catalog: \#2178) and p-HSL (catalog: \#4139), were purchased from Cell Signaling Technology (Bedford, MA, USA). Secondary antibody, anti-glyceraldehyde 3-phosphate dehydrogenase (GAPDH, catalog: sc-66163), and anti-SREBP-1 (catalog: sc-365513) were purchased from Santa Cruz Biotechnology (Santa Cruz, CA, USA).

\subsection{Isolation and Purification of (-)-loliolide from S. horneri}

The $S$. horneri was collected from the coastline of Jeju Island, Korea. The collected $S$. horneri was carefully washed using tap water and placed in a deep freezer for $24 \mathrm{~h}$. Frozen S. horneri was lyophilized and ground using a grinder. A detailed purification method of (-)-loliolide was followed as previously described by Kim et al. (2020) [31]. Briefly, $100 \mathrm{~g}$ of the $S$. horneri powder samples was extracted under the optimal ethanol extraction conditions $\left(37^{\circ} \mathrm{C}, 24 \mathrm{~h}\right)$ in the shaking incubator. After $24 \mathrm{~h}$ of incubation, S. horneri $70 \%$ ethanol extracts (SHE) were filtered through Whatman No. 4 filter paper and dried under the vacuumed rotary evaporator using the volume flask. The dried samples were collected from the flask and lyophilized by freeze dryer (SFDSM06, SAMWON, Busan, Korea). The dried SHE was stored in the $-80{ }^{\circ} \mathrm{C}$ freezer before use. The solvent fractionation was conducted on SHE. The dried SHE dissolved and fractionated with solvents (hexane, $\mathrm{HX}$; chloroform, $\mathrm{CHCl}_{3}$; ethyl acetate, $\mathrm{EA}$; and butanol, $\mathrm{BtOH}$ ) sequentially. Among the solvent fractions, the $\mathrm{CHCl}_{3}$ fractions were collected from SHE and concentrated under the vacuum rotary evaporator. The partitioned $\mathrm{CHCl}_{3}$ was stored in the freezer at $-80{ }^{\circ} \mathrm{C}$ for centrifugal partition chromatography (CPC). The CPC was adopted for isolate active compounds from SHE. The CPC column was equilibrated with the stationary phase and rotated at $1000 \mathrm{rpm}$. After the equilibration, the target sample was injected to the CPC device, and the mobile phase was eluted into the column in the descending mode at a flow rate of $2 \mathrm{~mL} / \mathrm{min}$. The CPC eluent was collected through fraction collector (FC 203B, Gilson, Villiers Le Bel, France). Then, high-performance liquid chromatography (HPLC) was conducted to further purify the active compound using a Prep HPLC system (Waters, Milford, MA, USA) equipped with a C18 (YMC-Pack, $5 \mu \mathrm{m}, 10 \times 250 \mathrm{~mm}$ ), octadecyl-silica (ODS) column. The HPLC separation conditions were as follows: The gradient elution was carried out using acetonitrile and distilled water at 0-60 $\mathrm{min}, 5: 95-100: 0 \mathrm{v} / \mathrm{v}$; and 60-70 $\mathrm{min}$, 100:0-100:0 $v / v$ at a flow rate of $3 \mathrm{~mL} / \mathrm{min}$. The UV absorbance was observed at $230 \mathrm{~nm}$ by a Waters 2998 photodiode array detector (Waters, Milford, MA, USA).

\subsection{Cell Culture and Differentiation}

The 3T3-L1 preadipocytes were purchased from the Korean cell line bank (KCLB). The cells were cultured in DMEM supplemented with $10 \%$ BS and 1\% P/S under humidified conditions $\left(5 \% \mathrm{CO} 2,37^{\circ} \mathrm{C}\right)$. The cells were subcultured every 2 days. To induce adipocyte differentiation, 3T3-L1 cells were plated in 12-well plates. Two days later, the cell confluence reached $100 \%$, and the cell culture medium was changed to DMEM medium (containing $10 \% \mathrm{FBS}$ and $1 \% \mathrm{P} / \mathrm{S}$ ) with differentiation solutions (MDI) consisting of $0.5 \mathrm{mM} \mathrm{IBMX}$, $0.25 \mu \mathrm{M}$ DM, and $5 \mu \mathrm{g} / \mathrm{mL}$ insulin at day 2. Subsequently, the cell culture medium was switched to DMEM containing $10 \%$ FBS and $1 \mu \mathrm{g} / \mathrm{mL}$ insulin and maintained for 4 days to induce additional adipocyte differentiation. After day 4 , the cell culture medium was replaced with fresh DMEM medium every 2 days. On day 8, 3T3-L1 cells were fixed and stained with $0.6 \%$ ORO solution to determine the accumulation of lipids in 3T3-L1 cells. 


\subsection{Cytotoxicity}

The cytotoxic effect of (-)-loliolide was evaluated via MTT assay, as previously described by Lee et al. (2020) [59]. The 3T3-L1 cells treated with various concentrations of (-)-loliolide $(0.125,0.25,0.5$, and $1 \mathrm{mM})$ were incubated for $48 \mathrm{~h}$ in 48 -well plates. After incubation, $75 \mu \mathrm{L}$ of MTT solution $(2 \mathrm{mg} / \mathrm{mL}$ ) was added to each well and incubated in the dark for another $4 \mathrm{~h}$. Subsequently, the well plates were centrifuged. After centrifugation, the supernatant was removed, and the precipitated formazan crystals, which were produced in the mitochondrial matrix of live cells, were dissolved in dimethyl sulfoxide (DMSO). To assess the cytotoxicity of (-)-loliolide, the formazan crystals were quantified and calculated using a microplate reader (Synergy ${ }^{\mathrm{TM}}$ HT Multi-Detection Microplate Reader, Bio-Tek, Winooski, VT, USA).

\subsection{Oil Red O Staining}

The specific lipid staining protocol was adopted to evaluate lipid accumulation in 3T3-L1 as previously described [60]. The 3T3-L1 cells were plated in 12-well plates, and adipocyte differentiation was induced with MDI solution for 8 days. During the adipocyte differentiation, the different concentrations of (-)-loliolide $(0.062,0.125,0.25,0.5$, and $1 \mathrm{mM})$ were treated on days $0,2,4$, and 6 except for the control group. On day 8 , differentiated 3T3-L1 cells were fixed with $10 \%$ formalin for $1 \mathrm{~h}$. Then, the fixed cells were washed twice with $60 \%$ 2-propanol and dried at $27^{\circ} \mathrm{C}$. The dried cell lipids were stained with $0.6 \%$ ORO solution for $2 \mathrm{~h}$ and again washed with distilled water (DW). After drying, ORO stain was eluted with $100 \%$ 2-propanol for $1 \mathrm{~h}$ in a shaking incubator. The relative ORO content was measured by Synergy ${ }^{\mathrm{TM}}$ HT Multi-Detection Microplate Reader (Bio-Tek, Winooski, VT, USA). The images of the intracellular lipids from 3T3-L1 cells were captured using a microscope (Lionheart ${ }^{\mathrm{TM}} \mathrm{FX}$ Automated Microscope, BioTek Instruments Inc., Winooski, VT, USA).

\subsection{Western Blot Analysis}

The effects of (-)-loliolide on the expression of adipose-specific proteins were investigated by Western blotting [61]. On day 8, differentiated 3T3-L1 cells were lysed in lysis buffer consisting of $5 \mathrm{mM}$ EDTA, $10 \mathrm{mM} \mathrm{Na} 4 \mathrm{P} 2 \mathrm{O} 7,10 \mathrm{mg} / \mathrm{mL}$ leupeptin, $100 \mathrm{mM} \mathrm{NaF}$, $1 \mathrm{mM}$ PMSF, $20 \mathrm{mM}$ Tris, $2 \mathrm{mM} \mathrm{Na} 3 \mathrm{VO} 4,10 \mathrm{mg} / \mathrm{mL}$ aprotinin, and $1 \%$ NP-40. Protein concentration in lysates was determined by bicinchoninic acid assay (BCA protein assay kit, Thermo Fisher Scientific, Rockford, IL, USA). Equal amounts of proteins were loaded on $10-12 \%$ of sodium dodecyl sulfate (SDS) acrylamide gel and separated by electrophoresis. The electrophoresed samples were transferred onto nitrocellulose membranes. The transferred membranes were blocked in $5 \%$ skim milk for $2 \mathrm{~h}$ at room temperature. Then, the membranes were incubated with primary antibodies $(1: 1000)$ overnight at $4{ }^{\circ} \mathrm{C}$. After incubation, the membranes were washed with $1 \times$ tris-buffered saline (TBST) three times, followed by incubation with secondary antibodies (1:1000) for $2-3 \mathrm{~h}$ at room temperature. Finally, the protein bands were imaged by Fusion Solo imaging system (Vilber Lourmat, Paris, France) using the enhanced chemiluminescence (ECL) Western blot detection kit.

\subsection{Statistical Analysis}

All data are presented as mean \pm standard deviation (SD), and experiments were performed at least three times. Statistical analysis was conducted using one-way ANOVA and Dunnett's multiple comparisons test in Graph Pad Prism 6 software. The significant differences were expressed as follows: ${ }^{* * * *} p<0.0001$.

\section{Conclusions}

In conclusion, the purified (-)-loliolide isolated from $70 \%$ ethanolic extract of $S$. horneri is a potential candidate for the development of a drug to inhibit lipid metabolism. (-)-loliolide may inhibit lipid metabolism by suppressing expression of adipogenic proteins and stimulating that of lipolytic and thermogenic proteins. However, large-scale 
observations are necessary to fully elucidate the inhibitory effect on lipid accumulation in detail. In conclusion, (-)-loliolide can be used as a valuable medicinal agent for the management of obesity.

Author Contributions: Conceptualization, Y.-J.J. and H.-G.L.; methodology, H.-S.K. and H.-G.L.; Software, K.K.A.S. and K.-M.S.; Resources, D.-S.L.; data curation, J.-G.J., Y.-S.C.; formal analysis, J.H. and M.-C.K.; writing_original draft preparation, H.-G.L.; project administration, Y.-J.J.; funding acquisition, Y.-J.J. All authors have read and agreed to the published version of the manuscript.

Funding: The "Basic Science Research Program" extended its support via the National Research Foundation of Korea (NRF), which is sponsored through the Ministry of Education (2018R1C1B6004780, 2019R1C1C1009327). Further, this research was supported by the National Marine Biodiversity Institute of Korea Research Program 2021M00500.

Institutional Review Board Statement: Not applicable.

Data Availability Statement: Not applicable.

Acknowledgments: The "Basic Science Research Program" extended its support via the National Research Foundation of Korea (NRF), which is sponsored through the Ministry of Education (2018R1C1B6004780, 2019R1C1C1009327). Further, this research was supported by the National Marine Biodiversity Institute of Korea Research Program 2021M00500.

Conflicts of Interest: The authors declare no conflict of interest.

\section{References}

1. Bluher, M. Obesity: Global epidemiology and pathogenesis. Nat. Rev. Endocrinol. 2019, 15, 288-298. [CrossRef] [PubMed]

2. Smith, K.B.; Smith, M.S. Obesity Statistics. Prim. Care 2016, 43, 121-135. [CrossRef] [PubMed]

3. Xu, S.; Xue, Y. Pediatric obesity: Causes, symptoms, prevention and treatment. Exp. Ther. Med. 2016, 11, 15-20. [CrossRef] [PubMed]

4. Shields, M.; Tremblay, M.S.; Gorber, S.C.; Janssen, I. Abdominal obesity and cardiovascular disease risk factors within body mass index categories. Health Rep. 2012, 23, 7-15. [PubMed]

5. Simmonds, M.; Llewellyn, A.; Owen, C.G.; Woolacott, N. Predicting adult obesity from childhood obesity: A systematic review and meta-analysis. Obes. Rev. 2016, 17, 95-107. [CrossRef] [PubMed]

6. Vucenik, I.; Stains, J.P. Obesity and cancer risk: Evidence, mechanisms, and recommendations. Ann. N. Y. Acad. Sci. 2012, 1271, 37-43. [CrossRef]

7. Faienza, M.F.; Chiarito, M.; Molina-Molina, E.; Shanmugam, H.; Lammert, F.; Krawczyk, M.; D'Amato, G.; Portincasa, P. Childhood obesity, cardiovascular and liver health: A growing epidemic with age. World J. Pediatr. 2020, 16, 438-445. [CrossRef]

8. Weihrauch-Bluher, S.; Kromeyer-Hauschild, K.; Graf, C.; Widhalm, K.; Korsten-Reck, U.; Jodicke, B.; Markert, J.; Muller, M.J.; Moss, A.; Wabitsch, M.; et al. Current Guidelines for Obesity Prevention in Childhood and Adolescence. Obes. Facts 2018, 11, 263-276. [CrossRef]

9. Gesta, S.; Tseng, Y.H.; Kahn, C.R. Developmental origin of fat: Tracking obesity to its source. Cell 2007, 131, 242-256. [CrossRef]

10. Howard, B.V.; Ruotolo, G.; Robbins, D.C. Obesity and dyslipidemia. Endocrinol. Metab. Clin. N. Am. 2003, 32, 855-867. [CrossRef]

11. Von Bibra, H.; Saha, S.; Hapfelmeier, A.; Muller, G.; Schwarz, P.E.H. Impact of the Triglyceride/High-Density Lipoprotein Cholesterol Ratio and the Hypertriglyceremic-Waist Phenotype to Predict the Metabolic Syndrome and Insulin Resistance. Horm. Metab. Res. 2017, 49, 542-549. [CrossRef] [PubMed]

12. Yang, C.S.; Wang, H.; Sheridan, Z.P. Studies on prevention of obesity, metabolic syndrome, diabetes, cardiovascular diseases and cancer by tea. J. Food Drug Anal. 2018, 26, 1-13. [CrossRef] [PubMed]

13. Han, T.S.; Lean, M.E. A clinical perspective of obesity, metabolic syndrome and cardiovascular disease. JRSM Cardiovasc. Dis. 2016, 5, 2048004016633371. [CrossRef] [PubMed]

14. Micha, R.; Mozaffarian, D. Saturated Fat and Cardiometabolic Risk Factors, Coronary Heart Disease, Stroke, and Diabetes: A Fresh Look at the Evidence. Lipids 2010, 45, 893-905. [CrossRef]

15. Laleh, P.; Yaser, K.; Alireza, O. Oleoylethanolamide: A novel pharmaceutical agent in the management of obesity-an updated review. J. Cell. Physiol. 2019, 234, 7893-7902. [CrossRef] [PubMed]

16. Bansal, A.B.; Al Khalili, Y. Orlistat. StatPearls 2020. [CrossRef]

17. Taltia, A.; Roy, A. Orlistat-an anti-obesity drug-An overview. J. Adv. Pharm. Educ. Res. 2017, 7.

18. Nwobodo, N. Toxicity and safety concerns in orlistat therapy for obesity: A critical evaluation. Asian J. Biomed. Pharm. Sci. 2015, $5,1$.

19. Wooltorton, E. Obesity drug sibutramine (Meridia): Hypertension and cardiac arrhythmias. CMAJ 2002, 166, 1307-1308. [PubMed] 
20. Fu, P.K.; Hsu, H.Y.; Wang, P.Y. Transient global amnesia after taking sibutramine: A case report. Neurologist 2010, 16, 129-131. [CrossRef] [PubMed]

21. Marrelli, M.; Statti, G.; Conforti, F. A Review of Biologically Active Natural Products from Mediterranean Wild Edible Plants: Benefits in the Treatment of Obesity and Its Related Disorders. Molecules 2020, 25, 649. [CrossRef]

22. Hu, X.Q.; Tao, N.P.; Wang, X.C.; Xiao, J.B.; Wang, M.F. Marine-derived bioactive compounds with anti-obesity effect: A review. J. Funct. Foods 2016, 21, 372-387. [CrossRef]

23. Yang, H.W.; Fernando, K.H.N.; Oh, J.Y.; Li, X.; Jeon, Y.J.; Ryu, B. Anti-Obesity and Anti-Diabetic Effects of Ishige okamurae. Mar. Drugs 2019, 17, 202. [CrossRef] [PubMed]

24. Liu, L.; Heinrich, M.; Myers, S.; Dworjanyn, S.A. Towards a better understanding of medicinal uses of the brown seaweed Sargassum in Traditional Chinese Medicine: A phytochemical and pharmacological review. J. Ethnopharmacol. 2012, 142, 591-619. [CrossRef] [PubMed]

25. Karadeniz, F.; Lee, S.-G.; Oh, J.H.; Kim, J.-A.; Kong, C.-S. Inhibition of MMP-2 and MMP-9 activities by solvent-partitioned Sargassum horneri extracts. Fish. Aquat. Sci. 2018, 21, 1-7. [CrossRef]

26. Chung, C.-Y.; Liu, C.-H.; Burnouf, T.; Wang, G.-H.; Chang, S.-P.; Jassey, A.; Tai, C.-J.; Tai, C.-J.; Huang, C.-J.; Richardson, C.D. Activity-based and fraction-guided analysis of Phyllanthus urinaria identifies loliolide as a potent inhibitor of hepatitis $C$ virus entry. Antivir. Res. 2016, 130, 58-68. [CrossRef] [PubMed]

27. Herath, K.H.I.N.M.; Cho, J.; Kim, A.; Kim, H.-S.; Han, E.J.; Kim, H.J.; Kim, M.S.; Ahn, G.; Jeon, Y.-J.; Jee, Y. Differential modulation of immune response and cytokine profiles of Sargassum horneri ethanol extract in murine spleen with or without Concanavalin A stimulation. Biomed. Pharmacother. 2019, 110, 930-942. [CrossRef] [PubMed]

28. Yang, X.; Kang, M.-C.; Lee, K.-W.; Kang, S.-M.; Lee, W.-W.; Jeon, Y.-J. Antioxidant activity and cell protective effect of loliolide isolated from Sargassum ringgoldianum subsp. coreanum. Algae 2011, 26, 201-208. [CrossRef]

29. Kwon, D.H.; Choi, Y.H.; Kim, B.W.; Hwang, H.J. Effects of Ethanol Extract of Sargassum horneri on Adipocyte Differentiation and Adipogenesis in 3T3-L1 Preadipocytes. J. Life Sci. 2019, 29, 209-214.

30. Yoshida, G.; Yoshikawa, K.; Terawaki, T. Growth and maturation of two populations of Sargassum horneri (Fucales, Phaeophyta) in Hiroshima Bay, the Seto Inland Sea. Fish. Sci. 2001, 67, 1023-1029. [CrossRef]

31. Kim, H.-S.; Wang, L.; Fernando, I.P.S.; Je, J.-G.; Ko, S.-C.; Kang, M.C.; Lee, J.M.; Yim, M.-J.; Jeon, Y.-J.; Lee, D.-S. Antioxidant efficacy of (-)-loliolide isolated from Sargassum horneri against AAPH-induced oxidative damage in Vero cells and zebrafish models in vivo. J. Appl. Phycol. 2020, 35, 3341-3348. [CrossRef]

32. Jemai, R.; Drira, R.; Makni, M.; Fetoui, H.; Sakamoto, K. Colocynth (Citrullus colocynthis) seed extracts attenuate adipogenesis by down-regulating PPAR $\gamma /$ SREBP-1c and C/EBP $\alpha$ in 3T3-L1 cells. Food Biosci. 2020, 33, 100491. [CrossRef]

33. Visscher, T.L.; Seidell, J.C. The public health impact of obesity. Annu. Rev. Public Health 2001, 22, 355-375. [CrossRef] [PubMed]

34. Cuzmar, V.; Alberti, G.; Uauy, R.; Pereira, A.; Garcia, C.; De Barbieri, F.; Corvalan, C.; Santos, J.L.; Mericq, V.; Villarroel, L.; et al. Early Obesity: Risk Factor for Fatty Liver Disease. J. Pediatr. Gastroenterol. Nutr. 2020, 70, 93-98. [CrossRef] [PubMed]

35. Emerenziani, S.; Guarino, M.P.L.; Asensio, L.M.T.; Altomare, A.; Ribolsi, M.; Balestrieri, P.; Cicala, M. Role of Overweight and Obesity in Gastrointestinal Disease. Nutrients 2020, 12, 111. [CrossRef] [PubMed]

36. Ryder, J.R.; Xu, P.; Inge, T.H.; Xie, C.; Jenkins, T.M.; Hur, C.; Lee, M.; Choi, J.; Michalsky, M.P.; Kelly, A.S.; et al. Thirty-Year Risk of Cardiovascular Disease Events in Adolescents with Severe Obesity. Obesity 2020, 28, 616-623. [CrossRef]

37. Forse, R.A.; Betancourt-Garcia, M.M.; Kissee, M.C. Epidemiology and discrimination in obesity. In The ASMBS Textbook of Bariatric Surgery; Springer: Berlin, Germany, 2020; pp. 3-14.

38. Nam, W.; Nam, S.H.; Kim, S.P.; Levin, C.; Friedman, M. Anti-adipogenic and anti-obesity activities of purpurin in 3T3-L1 preadipocyte cells and in mice fed a high-fat diet. BMC Complement. Altern. Med. 2019, 19, 364. [CrossRef]

39. Li, N.; Fu, X.; Xiao, M.; Wei, X.; Yang, M.; Liu, Z.; Mou, H. Enzymatic preparation of a low-molecular-weight polysaccharide rich in uronic acid from the seaweed Laminaria japonica and evaluation of its hypolipidemic effect in mice. Food Funct. 2020, 11, 2395-2405. [CrossRef] [PubMed]

40. Wang, Z.; Su, Y.; Li, K.; Zhao, L.; Liu, X. Hypolipidemic Effects of Polysaccharides from Fermented Seaweed. In IOP Conference Series: Materials Science and Engineering; IOP Publishing: Bristol, UK, 2019; p. 022070.

41. Yang, T.H.; Chiu, C.Y.; Lu, T.J.; Liu, S.H.; Chiang, M.T. The Anti-Obesity Effect of Polysaccharide-Rich Red Algae (Gelidium amansii) Hot-Water Extracts in High-Fat Diet-Induced Obese Hamsters. Mar. Drugs 2019, 17, 532. [CrossRef]

42. Yuan, Y.; Liu, Q.; Zhao, F.; Cao, J.; Shen, X.; Li, C. Holothuria Leucospilota Polysaccharides Ameliorate Hyperlipidemia in High-Fat Diet-Induced Rats via Short-Chain Fatty Acids Production and Lipid Metabolism Regulation. Int. J. Mol. Sci. 2019, 20, 4738. [CrossRef] [PubMed]

43. Cao, J.; Wang, S.C.; Yao, C.W.; Xu, Z.; Xu, X.M. Hypolipidemic effect of porphyran extracted from Pyropia yezoensis in ICR mice with high fatty diet. J. Appl. Phycol. 2016, 28, 1315-1322. [CrossRef]

44. Seo, Y.J.; Kim, K.J.; Choi, J.; Koh, E.J.; Lee, B.Y. Spirulina maxima Extract Reduces Obesity through Suppression of Adipogenesis and Activation of Browning in 3T3-L1 Cells and High-Fat Diet-Induced Obese Mice. Nutrients 2018, 10, 712. [CrossRef]

45. Wang, Y.M.; Pan, X.; He, Y.; Chi, C.F.; Wang, B. Hypolipidemic Activities of Two Pentapeptides (VIAPW and IRWWW) from Miiuy Croaker (Miichthys miiuy) Muscle on Lipid Accumulation in HepG2 Cells through Regulation of AMPK Pathway. Appl. Sci. 2020, 10, 817. [CrossRef] 
46. Fajas, L.; Schoonjans, K.; Gelman, L.; Kim, J.B.; Najib, J.; Martin, G.; Fruchart, J.C.; Briggs, M.; Spiegelman, B.M.; Auwerx, J. Regulation of peroxisome proliferator-activated receptor gamma expression by adipocyte differentiation and determination factor 1/sterol regulatory element binding protein 1: Implications for adipocyte differentiation and metabolism. Mol. Cell. Biol. 1999, 19, 5495-5503. [CrossRef] [PubMed]

47. Crewe, C.; Zhu, Y.; Paschoal, V.A.; Joffin, N.; Ghaben, A.L.; Gordillo, R.; Oh, D.Y.; Liang, G.; Horton, J.D.; Scherer, P.E. SREBPregulated adipocyte lipogenesis is dependent on substrate availability and redox modulation of mTORC1. JCI Insight 2019, 4, e129397. [CrossRef]

48. Mandrup, S.; Lane, M.D. Regulating adipogenesis. J. Biol. Chem. 1997, 272, 5367-5370. [CrossRef] [PubMed]

49. Morrison, R.F.; Farmer, S.R. Hormonal signaling and transcriptional control of adipocyte differentiation. J. Nutr. 2000, 130, 3116S-3121S. [CrossRef] [PubMed]

50. Storch, J.; Thumser, A.E. The fatty acid transport function of fatty acid-binding proteins. Biochim. Biophys. Acta 2000, 1486, 28-44. [CrossRef]

51. Kim, J.B.; Wright, H.M.; Wright, M.; Spiegelman, B.M. ADD1/SREBP1 activates PPAR $\gamma$ through the production of endogenous ligand. Proc. Natl. Acad. Sci. USA 1998, 95, 4333-4337. [CrossRef] [PubMed]

52. Horton, J.D.; Shah, N.A.; Warrington, J.A.; Anderson, N.N.; Park, S.W.; Brown, M.S.; Goldstein, J.L. Combined analysis of oligonucleotide microarray data from transgenic and knockout mice identifies direct SREBP target genes. Proc. Natl. Acad. Sci. USA 2003, 100, 12027-12032. [CrossRef]

53. Magre, J.; Laurell, H.; Fizames, C.; Antoine, P.J.; Dib, C.; Vigouroux, C.; Bourut, C.; Capeau, J.; Weissenbach, J.; Langin, D. Human hormone-sensitive lipase: Genetic mapping, identification of a new dinucleotide repeat, and association with obesity and NIDDM. Diabetes 1998, 47, 284-286. [CrossRef] [PubMed]

54. Finck, B.N.; Kelly, D.P. PGC-1 coactivators: Inducible regulators of energy metabolism in health and disease. J. Clin. Investig. 2006, 116, 615-622. [CrossRef] [PubMed]

55. Wan, Z.; Root-Mccaig, J.; Castellani, L.; Kemp, B.E.; Steinberg, G.R.; Wright, D.C. Evidence for the role of AMPK in regulating PGC-1 alpha expression and mitochondrial proteins in mouse epididymal adipose tissue. Obesity 2014, 22, 730-738. [CrossRef]

56. Khan, S.A.; Sathyanarayan, A.; Mashek, M.T.; Ong, K.T.; Wollaston-Hayden, E.E.; Mashek, D.G. ATGL-catalyzed lipolysis regulates SIRT1 to control PGC-1alpha/PPAR-alpha signaling. Diabetes 2015, 64, 418-426. [CrossRef]

57. Kim, S.J.; Tang, T.Y.; Abbott, M.; Viscarra, J.A.; Wang, Y.H.; Sul, H.S. AMPK Phosphorylates Desnutrin/ATGL and HormoneSensitive Lipase To Regulate Lipolysis and Fatty Acid Oxidation within Adipose Tissue. Mol. Cell. Biol. 2016, 36, 1961-1976. [CrossRef]

58. Lu, Y.A.; Lee, H.G.; Li, X.; Hyun, J.M.; Kim, H.S.; Kim, T.H.; Kim, H.M.; Lee, J.J.; Kang, M.C.; Jeon, Y.J. Anti-obesity effects of red seaweed, Plocamium telfairiae, in C57BL/ 6 mice fed a high-fat diet. Food Funct. 2020, 11, 2299-2308. [CrossRef]

59. Lee, H.G.; Lu, Y.A.; Li, X.; Hyun, J.M.; Kim, H.S.; Lee, J.J.; Kim, T.H.; Kim, H.M.; Kang, M.C.; Jeon, A.Y. Anti-Obesity Effects of Grateloupia elliptica, a Red Seaweed, in Mice with High-Fat Diet-Induced Obesity via Suppression of Adipogenic Factors in White Adipose Tissue and Increased Thermogenic Factors in Brown Adipose Tissue. Nutrients 2020, 12, 308. [CrossRef] [PubMed]

60. Kang, M.C.; Kang, N.; Ko, S.C.; Kim, Y.B.; Jeon, Y.J. Anti-obesity effects of seaweeds of Jeju Island on the differentiation of 3T3-L1 preadipocytes and obese mice fed a high-fat diet. Food Chem. Toxicol. 2016, 90, 36-44. [CrossRef] [PubMed]

61. Kang, M.C.; Ding, Y.L.; Kim, H.S.; Jeon, Y.J.; Lee, S.H. Inhibition of Adipogenesis by Diphlorethohydroxycarmalol (DPHC) through AMPK Activation in Adipocytes. Mar. Drugs 2019, 17, 44. [CrossRef] [PubMed] 